\title{
ASSESSING THE IMPACT OF LAND USE AND LAND COVER ON WATER QUALITY IN THE WATERSHED OF A RESERVOIR
}

\author{
BONANSEA, M. ${ }^{1,2^{*}}-$ LEDESMA ${ }^{2}{ }^{2}-$ RODRIGUEZ, M. C. $^{2}$ \\ ${ }^{1}$ Consejo Nacional de Investigaciones Científicas y Técnicas(CONICET), Ruta Nacional $36 \mathrm{Km}$ \\ 601. (5800) Río Cuarto, Córdoba, Argentina \\ ${ }^{2}$ Departamento de Estudios Básicos y Agropecuarios, Facultad de Agronomía y Veterinaria \\ (FAyV), Universidad Nacional de Río Cuarto (UNRC), Ruta Nacional 36 Km 601. (5800) Río \\ Cuarto, Córdoba, Argentina \\ "Corresponding author \\ e-mail:mbonansea@ayv.unrc.edu.ar \\ (phone: +54-358-467-6512; fax :+54-358-468-0280) \\ (Received $3^{\text {rd }}$ Aug 2015; accepted $20^{\text {th }}$ Feb 2016)
}

\begin{abstract}
Natural forest of Río Tercero watershed (Argentina) was replaced by urban expansion and agricultural activities causing negative impacts in water quality of Río Tercero reservoir. This paper classifies land use and land cover (LULC) in the watershed, trying to find a relationship with nutrient loads of the reservoir's tributaries. Each tributary was analysed during 2006 bimonthly for physicochemical variables. LULC was determined using a Landsat 5 TM image. Statistical analyses were carried out to identify relationships between water quality and LULC. Results suggest that urban and agricultural activities are the primary driving forces behind the variations in nutrient loads measured in tributaries. Sub-watershed most affected by human activities displayed the highest values of nutrient loads. If agricultural and urban activities continue to increase, water quality at watershed scale will decline. It is recommended the development of a global approach management plan at a watershed scale.
\end{abstract}

Keywords: basin, land use change, nutrient loads, water quality, water resources

\section{Introduction}

Lakes and reservoirs are important freshwater sources used to satisfy environmental and human needs. Unfortunately, in recent years there is a rapid declining availability of usable freshwater in terms of water quality and quantity due to unsustainable land use practices and urban land development.

Studies demonstrate that surface water quality is controlled by both the natural processes (i.e. precipitation inputs, erosion, and weathering) and the anthropogenic activities via point sources, such as industrial effluents and wastewater treatment facilities, and diffuse, such as runoffs from farming land and urban area (Ahearn et al., 2005; Li et al., 2009). On this sense, Seeboonruang (2012) and $\mathrm{Su}$ et al. (2015) found that different land use types and spatial patterns greatly affect water quality. According to Lee and Bastemeijer (1991), many problems of water pollution are caused by changes in land use patterns on watershed areas as population pressure and economic activity increase. Li et al. (2008) found that there is a strong relationship between declining water quality and increasing agricultural and urban land development at watershed scale. Ngoye and Machiwa (2004) concluded that areas close to human and agricultural activities significantly contributed to higher concentrations of nutrients concentration than natural areas. Tong and Chen (2002), studying the contribution of pollutants from different types of land use, found that agricultural land use produced the highest and bare land use the least amount of contaminants. Awotwi et al. (2015) found that human 
activity is one of the major driving forces leading to changes in land cover characteristics and subsequently hydrologic processes. Wang (2001) found that industrial land and agricultural land decrease water environment quality and forest land and grassland have a negative influence on water pollutant concentration. Water quality in rivers is generally linked with land use in the watershed that can affect the amount and quality of runoff during and following rainfall. This is support by Richards and Host (1994) who suggest that forestry, agriculture, industrialization and urbanization modify watershed cover characteristics that influence runoff quality. Therefore, there is an increasing need to monitor and assess agricultural activities and urban expansion precisely at watershed scale (Howell et al., 2012; Ouedraogo et al., 2010).

Satellite remote sensing offers an alternative option for analysing land use and land cover (LULC) at a regional scale because it facilitates observations across larger regions and at higher frequencies than ground-based observations (Schulz et al., 2010; Shen et al., 2013). Among different sensors that have been used with this aim, the Landsat series of satellites provides the longest continuous record of satellite-based observations, being the primary source of medium spatial resolution Earth observations used in decision-making and an invaluable resource for monitoring global change (Hadjimitsis et al., 2010; Loveland and Dwyer, 2012). This series of satellite missions has collected imagery of the Earth's surface since 1972, providing an unparalleled record of the status and dynamics of Earth (Cohen and Goward, 2004). The Landsat 5 TM is equipped with a multi-spectral scanning equipment, which operates on seven spectral bands located between the visible and infrared regions of the spectrum. The spatial resolution is $30 \mathrm{~m}$ for the visible through middle infrared channels and $120 \mathrm{~m}$ for thermal infrared band, allowing the detection of small scale spatial variability across a reservoir surface (Xu et al., 2013). This sensor present a revisit time of 16 days and a radiometric resolution of 256 digital numbers (DN) (Oguro et al., 2003; Loveland and Dwyer, 2012).

In the central region of Argentina, considerable changes in LULC have taken place over the past four decades mostly due to population increase, the spread of settlement and the increasing use of land resources for agriculture and economic development. Thus, the main objective of this study was to classify LULC in the watershed of Río Tercero reservoir (Argentina), trying to find a relationship with nutrient loads supplied of its tributaries. This study, which is the first study that explores the current extend of land cover types in Central Argentina, tries to demonstrate the useful of LULC detection by remote sensing in those regions where there is a lack of available cartographic information with sufficient spatial resolution, obtaining a relationship with water quality of reservoir's tributaries allowing the development of strategies for conservation, sustainable management and restoration planning at watershed scale.

\section{Materials and Methods}

\section{Study area}

Río Tercero watershed located in Córdoba province (Argentina), has an area of 3000 $\mathrm{Km}^{2}$ approximately and is divided in five sub-watersheds (Fig. 1). In last decades, natural forest of the watershed, characterized by dry woodland alternating with hard grasses (Cabrera, 1976), was replaced by urban expansion and agricultural activities, causing negative impacts in water quality of Río Tercero reservoir (Bonansea et al., 2015a). This reservoir, which is the largest artificial reservoir in the province, has an 
area of $46 \mathrm{~km}^{2}$, a volume of $107 \mathrm{~m}^{3}$ and maximum and mean depths of 46.5 and $12.2 \mathrm{~m}$, respectively (Ledesma et al., 2013). The reservoir has multiple purposes such as water supply, power generation, flood control, irrigation, tourism and recreational activities (Bonansea et al., 2015b). According to Mac Donagh et al. (2009), rainfall is strongly seasonal, with dry winters and heavy rains during spring and summer.

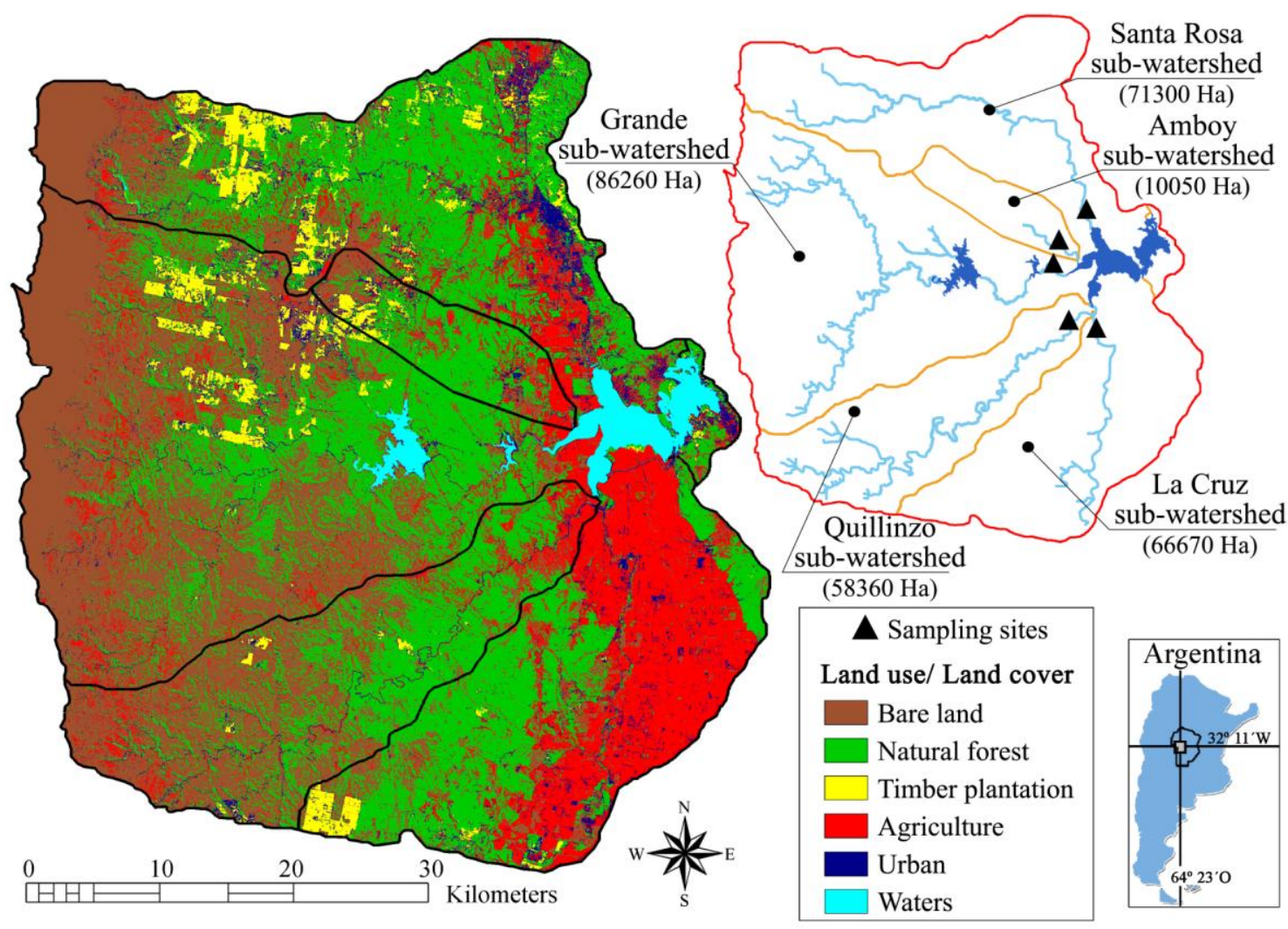

Figure 1. Position of sampling sites, land use and land cover of Rio Tercero watershed

\section{Field measurements}

Each tributary of Río Tercero reservoir was analysed during 2006 bimonthly for physico-chemical variables, representing the dry season (April-September) and the rainy season (October-March) (Fig. 1). Coordinates of sample sites were recorded using a GPS device. In-situ, water temperature (WT), $\mathrm{pH}$, dissolved oxygen, (DO) and stream flows (Q) were measured using portable electronic instruments. Total phosphorus (TP) and total nitrogen (TN) were determined in laboratory according to standard analytical methods and protocols (APHA-AWWA-WEF, 2000). Nutrient loads, defined as the total amount of TP and NT entering in the reservoir by each tributary during a given time were measured.

\section{Land use and land cover analysis}

The September 20th 2006 free of clouds image from Landsat 5 Thematic Mapper (TM) (Path: 229; Row: 82), downloaded from the USGS Global Visualization Viewer (http://glovis.usgs.gov), was used to determine LULC in the studied watershed. Six land cover categories were defined as (1) bare land, including gravels, bare ground and bare 
rocks; (2) natural forest, including natural shrubs, thickets and herb; (3) timber plantation, including coniferous (Pinus taheda, P. Radiata, P. Insignias, P. Elliotis, among others); (4) agriculture, including agricultural and livestock developments; (5) urban, including industrial and residential areas; (6) waters, including rivers, reservoirs, wetlands and sandy beach. The TM image was classified according to the resulting six land cover classes using the maximum likelihood algorithm (Chuvieco, 2002) (Fig. 1). This classifier has proven to be a robust and consistent classifier for multi-date classifications (Shalaby and Tateishi, 2007).

\section{Statistical analyses}

One-way analysis of variance (ANOVA) was employed as a first approach to analyse the significant differences between water quality variables $(p<0.05$; least-significance difference, LSD test). Pearson correlation coefficients and stepwise multiple regression analysis were carried out to investigate the relationships between water quality parameters and LULC $(\mathrm{p}<0.05)$. The Root Mean Square of the Error (RMSE), which gives an estimate of the error associated with the estimations was calculated according to Matthews et al. (2010).

\section{Results and discussion}

\section{Water quality of tributaries}

The basic statistics of water quality parameters collected in tributaries of Río Tercero reservoir are presented in Table 1. WT, Q and nutrient loads (PT and NT load) showed significant variations ( $p>0.05)$ between dry and rainy season. WT and Q were higher in rainy season, coinciding with normal variation of atmospheric temperature and rainfall. The higher load of nutrients also occurred in rainy season when river runoff was higher.

Table 1. Mean values of water quality parameters measured in Río Tercero reservoir tributaries

\begin{tabular}{|c|c|c|c|c|c|c|}
\hline \multirow{2}{*}{ Parameter } & \multirow{2}{*}{ Season } & \multicolumn{5}{|c|}{ Tributary } \\
\hline & & Santa Rosa & Amboy & Grande & Quillinzo & La Cruz \\
\hline \multirow{2}{*}{$\begin{array}{l}\text { WT } \\
\left({ }^{\circ} \mathrm{C}\right)\end{array}$} & Dry & 20.2 & 18.1 & 17.2 & 16.0 & 14.4 \\
\hline & Rainy & 26.5 & 27.0 & 29.3 & 29.5 & 18.9 \\
\hline \multirow{2}{*}{$\mathrm{pH}$} & Dry & 8.82 & 8.36 & 7.49 & 7.42 & 6.96 \\
\hline & Rainy & 7.62 & 7.79 & 6.64 & 6.73 & 7.59 \\
\hline \multirow{2}{*}{$\begin{array}{c}\mathrm{DO} \\
(\mathrm{mg} / \mathrm{L})\end{array}$} & Dry & 8.5 & 7.2 & 8.0 & 8.7 & 9.5 \\
\hline & Rainy & 9.1 & 7.5 & 8.6 & 9.3 & 9.8 \\
\hline \multirow{2}{*}{$\begin{array}{c}\mathrm{Q} \\
(\mathrm{L} / \mathrm{seg})\end{array}$} & Dry & 13.8 & 1.6 & 7.4 & 2.4 & 7.3 \\
\hline & Rainy & 14205.0 & 567.7 & 696.3 & 5231.2 & 6469.5 \\
\hline \multirow{2}{*}{$\begin{array}{c}\mathrm{PT} \\
(\mathrm{mg} / \mathrm{L})\end{array}$} & Dry & 0.07 & 0.07 & 0.03 & 0.03 & 0.07 \\
\hline & Rainy & 0.02 & 0.03 & 0.03 & 0.02 & 0.04 \\
\hline \multirow{2}{*}{$\begin{array}{c}\mathrm{NT} \\
(\mathrm{mg} / \mathrm{L})\end{array}$} & Dry & 3.1 & 1.1 & 1.7 & 1.5 & 1.7 \\
\hline & Rainy & 0.9 & 1.1 & 1.4 & 0.9 & 1.5 \\
\hline \multirow{2}{*}{$\begin{array}{l}\text { PT load } \\
\text { (T/year) }\end{array}$} & Dry & 0.03 & 0.01 & 0.01 & 0.01 & 0.02 \\
\hline & Rainy & 8.78 & 0.47 & 0.64 & 2.69 & 8.89 \\
\hline \multirow{2}{*}{$\begin{array}{l}\text { NT load } \\
\text { (T/year) }\end{array}$} & Dry & 1.35 & 0.06 & 0.39 & 0.11 & 0.39 \\
\hline & Rainy & 403.17 & 19.69 & 30.74 & 148.47 & 306.69 \\
\hline
\end{tabular}




\section{Land use and cover analysis}

The TM image was usefull to classify LULC in the watershed of Río Tercero reservoir (Fig. 1). Figure 2 shows that bare land and natural forest were the dominant land cover types. Bare land ranged from $12.1 \%$ in La Cruz sub-watershed to $54.6 \%$ in Grande subwatershed. Timber plantation was comprised from $7.4 \%$ in Santa Rosa sub-watershed to $0.8 \%$ in Quillinzo sub-watershed. Natural forest covered from $29.5 \%$ in Grande subwatershed to 56.5\% in Amboy sub-watershed. Although agricultural activities were widely distributed across the basin but it mainly concentrated in La Cruz and Santa Rosa subwatersheds, comprising around 46.0 and $28.5 \%$ of its land area respectively. Urban category ranged from 3.7 to $10.2 \%$ in Grande and Santa Rosa sub-watersheds respectively. Waters covered less than $0.1 \%$ of the sub-watersheds area except in Grande watershed (1.4\% of its respective land area) where reservoirs are interconnected.

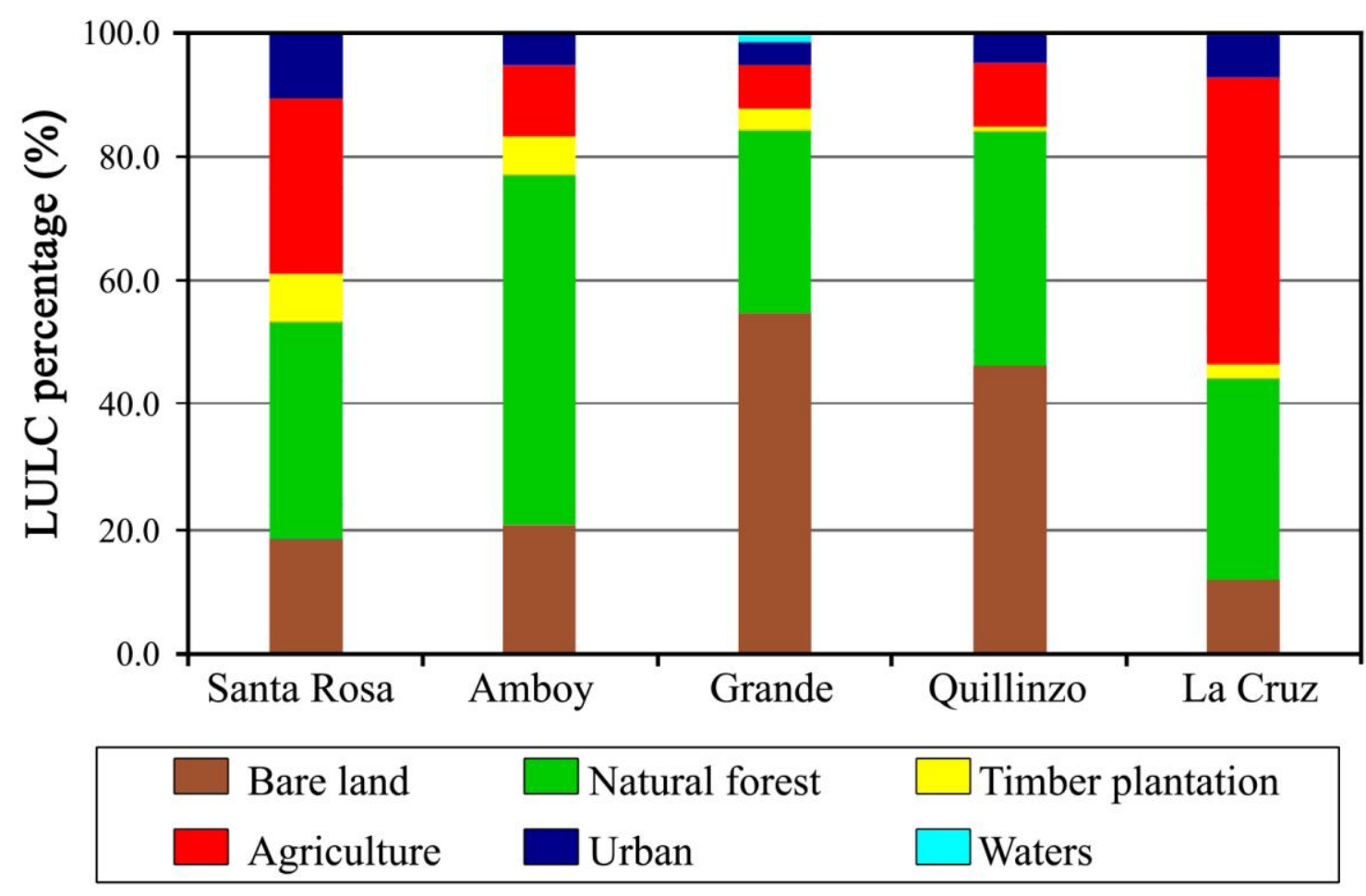

Figure 2. Land use and land cover composition of Rio Tercero reservoir sub-watersheds

\section{Relationship between LULC and water quality parameters}

Correlation and regression analyses were performed by analysing the average values of water quality parameters and the area covered by LULC on each sub-watershed (Table 2, 3). These analyses indicate distinct influence of land use on water quality parameters. Only those correlation values higher than 0.5 were considered (Table 2). Results show that bare land presents significantly negative correlation with PT, and timber plantation has a strong positive correlation with NT. High and positive correlation was observed between nutrient loads and agriculture, which also contributes to WT, DO, Q, PT and NT. Natural forest has positive association with DO and NT, while urban has strong positive correlation to NT, NT load and Q, and also contributes to PT load and DO. 
Table 2. Pearson correlation coefficients between LULC and water quality parameters in Rio Tercero watershed

\begin{tabular}{c|c|c|c|c|c|c}
\hline Parameter & Waters & Bare land & Timber plantation & Agriculture & Natural forest & Urban \\
WT & 0.30 & 0.41 & 0.28 & $-\mathbf{0 . 7 5}$ & -0.02 & -0.12 \\
pH & -0.47 & $\mathbf{- 0 . 6 7}$ & 0.41 & 0.01 & -0.44 & 0.20 \\
DO & -0.19 & 0.05 & 0.15 & $\mathbf{0 . 8 1}$ & $\mathbf{0 . 7 1}$ & $\mathbf{0 . 6 4}$ \\
Q & -0.45 & -0.28 & $\mathbf{0 . 6 9}$ & $\mathbf{0 . 6 4}$ & 0.49 & $\mathbf{0 . 9 0}^{\mathbf{b}}$ \\
PT & -0.47 & $\mathbf{- 0 . 8 2}^{\mathbf{b}}$ & 0.08 & $\mathbf{0 . 5 6}$ & -0.42 & 0.15 \\
NT & 0.12 & 0.07 & $\mathbf{0 . 9 3}^{\mathbf{b}}$ & $\mathbf{0 . 6 8}^{\mathbf{b}}$ & $\mathbf{0 . 7 0}$ & $\mathbf{0 . 9 6}^{\mathbf{a}}$ \\
PT load & -0.46 & -0.42 & 0.50 & $\mathbf{0 . 9 4}^{\mathbf{b}}$ & 0.45 & $\mathbf{0 . 8 5}^{\mathbf{b}}$ \\
NT load & -0.47 & -0.36 & $\mathbf{0 . 5 9}$ & $\mathbf{0 . 8 4}^{\mathbf{b}}$ & 0.50 & $\mathbf{0 . 9 1}^{\mathbf{b}}$ \\
\hline
\end{tabular}

Table 3. Stepwise multiple regression analysis $(p<0.05)$ for water quality parameters and LULC in Rio Tercero watershed

\begin{tabular}{c|c|c|c|c|c}
\hline \multirow{2}{*}{ Parameter } & \multicolumn{2}{|c|}{ Regression equation coefficients } & \multirow{2}{*}{$\mathbf{R}^{2}$} & \multirow{2}{*}{ RMSE } \\
\cline { 2 - 4 } & Agriculture & Urban & Constant & & \\
\hline NT & & $1.4 * 10^{-4}$ & 0.98 & 0.91 & 0.09 \\
PT load & $1.6 * 10^{-4}$ & & 0.05 & 0.88 & 0.64 \\
NT load & $2.6 * 10^{-3}$ & 0.02 & -21.03 & 0.88 & 18.86 \\
\hline
\end{tabular}

Stepwise multiple regression analysis between water quality values and LULC indicated distinct influence of land cover on water quality parameters related with nutrients availability. As shown in Table 3, no single land cover type was able to describe the overall water quality, but some water quality parameters could be sufficiently predicted using one or two LULC according to the good fit between observed and estimated values $\left(\mathrm{R}^{2}>0.80\right)$ and the lower and reasonable error associated with the estimations (RMSE). NT could be predicted by urban area $\left(\mathrm{R}^{2}=0.91\right)$. PT load was predicted by agriculture $\left(\mathrm{R}^{2}=0.88\right)$ and NT load by agriculture and urban activities $\left(\mathrm{R}^{2}=0.88\right)$. Results suggest that urban and agricultural activities could be the primary driving forces behind the variations in nutrient concentrations.

\section{Discussion}

Our results demonstrated that, larger sub-watershed where urban and agricultural activities were more frequents, displayed the highest values of nutrients concentration and nutrient loads, as the case of Santa Rosa and La Cruz sub-watersheds.

Comparing our results with the physiognomic vegetation map of the studied watershed published by Menghi and Luti (1982), we observed that natural forest showed the largest decline. During this period, natural vegetation revealed a general trend of a continuous reduction that in turn has led to an increase in human-induced types of land uses such as agricultural and urban residential developments. According to Schulz et al. (2010), in SouthAmerica the strong increases in agriculture activities has been stimulated by a combination of market liberalisation, incentives for new exportoriented crops, introduction of new irrigation technologies, and improvements in road infrastructure, while the expansion of urban areas coincided with population growth and the liberalisation of the urban land market. 
In last decades Río Tercero watershed has shown a reduction of natural forest, which has been replaced by agricultural activities and urban expansion which do not have adequate waste treatment facilities, directly discharging to water bodies, which resulted in decrease of water quality. Further, vegetation loss and degradation reduce precipitation infiltration and runoff regulation, which promotes soil erosion and has a negative impact on ground water recharge (Schulz et al., 2010). Currently, using a TM image we have estimated that $32 \%\left(937.9 \mathrm{~km}^{2}\right)$ of the entire watershed area is related with human-induced types of land uses. Because of the policies adopted by governments, increases in these activities over time are expected. Thus, efforts within the watershed should be focused to develop a planning process in which agriculture and urban interests with responsibility for water quality are shared. Addressing these issues together is essential to avoid short-term counterproductive conflicts and to develop a long-term vision for the watershed (Fisher et al., 2000).

In this study we have demonstrate that tributaries of Río Tercero reservoir whose watersheds were most affected by human activities, displayed the highest values of nutrient loads, as the case of Santa Rosa and La Cruz rivers. This is in agreement with different studies that suggest that the percentage of agriculture and urbanized areas at watershed scale are the primary predictor for nutrients (Ahearn et al., 2005; Li et al., 2008; Schulz et al., 2010). In addition, Chang (2008) and Li et al. (2009) found that these land uses trend to increase nitrogen and phosphorus non-points-source pollution. Thus, these parameters could be predicted using agricultural and urban activities. However different studies have demonstrated interactions between LULC and other water constituents of inland water which are also complex and important. In this sense, Tong and Chen (2002) suggest that in addition to nutrients, fecal coliform bacteria have strong positive relationships with agricultural and urban use. Li et al. (2008) also measured suspended particle matter (SPM), potassium permanganate index (IMn) and dissolved phosphorus (DP), finding relationship with agricultural and urban land cover. Urban cover positively influences chemical oxygen demand (COD) and biochemical oxygen demand (BOD) in the Han River basin, South Korea (Chang, 2008). Unfortunately, we do not have collected ancillary data such as fecal coliform, SPM, COD or BOD measures to related with our results. However, we recommend that when more information is known, this information should be used when it considerably improves estimates.

On the other hand, the effects of change in land use and the subsequent decrease of tributaries water quality, has also been observed in Río Tercero reservoir. Thus, Ledesma et al. (2013) have shown that in the reservoir chlorophyll-a concentration (Chl-a) was higher close to river inputs and decreased toward the rest of the reservoir, evidencing the presence of a longitudinal zonification. This relationship could be related with larger river runoff with higher nutrients availability generated by watershed washout or water runoff from agricultural fields after rainfall (Bonansea et al., 2015b). This is in agreement with several investigators that have studied the effect of discharge of nutrients in different water bodies causing algal blooms and eutrophication (Nishimura et al., 2002; Shukla et al., 2008). An opposite pattern was observed in water clarity expressed in terms of Secchi disk transparency (SDT) where river inputs provide the greatest loads of suspended materials and dissolved solids that decrease the penetration of light (Bonansea et al., 2015b). A similar spatial pattern of lower SDT near river inflows and increasing with distance was found by Bazán et al. (2005), Giardino et al. (2010), and Guan et al. (2011) in different water bodies. 
Like most previous studies of water quality in relation to LULC, we focus on only one watershed, but the transferability to other environments remains unknown. However, similar characteristics of other watersheds of the region suggest that future research may allow the extension of such methodologies to the regional scale, allowing the study of dynamics of many watershed that currently lack systematic studies of water quality.

\section{Conclusions}

Using a TM image we could classify different LULC in the watershed of Río Tercero reservoir. Statistical analyses were used to identify and quantify the magnitude, direction, and significance of relationships between water quality and LULC.

Results showed that land use was related to water quality parameters. Thus, humaninduced types of land uses such as agricultural and urban cover were the primary driving forces behind the variations in nutrient loads. We expect that if agricultural activities and urban residential developments continue to increase in Río Tercero watershed, water quality at watershed scale will decline. Therefore, to assess water quality of Río Tercero reservoir, it is recommended the development of a global approach management plan at a watershed scale, taking account river runoff, land use and land cover, and allowing the implementation of strategies for ensure sustainable development and preservation of water supply.

This study can have direct application values to state or local agencies, city planners and water management authorities and decision makers for defining the impacts of land use on water resources and for implementing long-term water planning and management scheme.

Acknowledgements. This work was supported by the CONICET and by the Science and Technique Secretary of the UNRC.

\section{REFERENCES}

[1] Ahearn, D., Sheibley, R., Dahlgren, R., Anderson, M., Jonson, J., Tate, K. (2005): Land use and land cover influence on water quality in the last free-flowing river draining the western Sierra Nevada, California. - Journal of Hydrology 313: 234-247.

[2] APHA-AWWA-WEF. (2000): Standard methods for the examination of water and wastewater. - APHA-AWWA-WEF, Washington DC.

[3] Awotwi, A., Yeboah, F., Kumi, M. (2015): Assessing the impact of land cover changes on water balance components of White Volta Basin in West Africa. - Water and Environment Journal 29(2): 259-267.

[4] Bazán, R., Corral, M., Pagot, M., Rodríguez, A., Rodríguez, N., Larrosa, N., Cossavella, A., Olmo S., Bonfanti, E., Busso, F. (2005): Teledetección y modelado numérico para el análisis de la calidad de agua del embalse Los Molinos. - Ingeniería hidráulica en México 20(2): 121-135.

[5] Bonansea, M., Ledesma, C., Rodríguez, C., Pinotti, L. (2015a) Water quality assessment using multivariate statistical techniques in Río Tercero Reservoir, Argentina. Hydrology Research 46(3), 377-387.

[6] Bonansea, M., Rodríguez, C., Pinotti, L., Ferrero, S. (2015b): Using multi-temporal Landsat imagery and linear mixed models for assessing water quality parameters in Río Tercero reservoir (Argentina). - Remote Sensing of Environment 158(1): 28-41. 
[7] Cabrera, A. (1976): Regiones fitogeográficas argentinas. - Acme, Buenos Aires.

[8] Chang, H. (2008): Spatial analysis of water quality trends in the Han River basin, South Korea. - Water Research 42(13): 3285-3304.

[9] Cohen, W.B., Goward, S.N. (2004): Landsat's role in ecological applications of remote sensing. - Bioscience 54(6): 535-545.

[10] Chuvieco, E. (2002): Teledetección ambiental. - Ariel S.A., Madrid.

[11] Fisher, D., Steiner, J., Endale, D., Stuedemann, J., Schomberg, H., Franzluebbers, A., Wilkinson, S. (2000): The relationship of land use practices to surface water quality in the Upper Oconee Watershed of Georgia. - Forest Ecology and Management 128(1): 39-48.

[12] Giardino, C., Bresciani, M., Villa, P., Martinelli, A. (2010): Application of remote sensing in water resource management: The case study of lake Trasimeno, Italy. - Water Resources Management 24(14): 3885-3899.

[13] Guan, X., Li, J., Booty, W.G. (2011): Monitoring lake Simcoe water clarity using Landsat-5 TMimages. - Water Resources Management 25(8): 2015-2033.

[14] Hadjimitsis, D.G., Clayton, C.R., Toulios, L. (2010): A new method for assessing the trophic state of large dams in Cyprus using satellite remotely sensed data. - Water and Environment Journal 24(3): 200-207.

[15] Howell, E.T., Chomicki, K.M., Kaltenecker, G. (2012): Patterns in water quality on Canadian shores of Lake Ontario: Correspondence with proximity to land and level of urbanization. - Journal of Great Lakes Research 38: 32-46.

[16] Ledesma, C., Bonansea, M., Rodríguez, C., Delgado, A (2013): Water quality control in Third River Reservoir (Argentina) using geographical information systems and linear regression models. - Ambiente Agua 8(2): 67-76.

[17] Lee, M.D., Bastemeijer, T.F. (1991): Drinking water source protection: a review of environmental factors affecting community water supplies. - IRC occasional paper (No. 15), The Hangue.

[18] Li, S., Gu, S., Liu, W., Han, H., Zhang, Q. (2008): Water quality in relation to land use and land cover in the upper Han River Basin, China. - Catena 75(2): 216-222.

[19] Li, S., Gu, S., Tan, X., Zhang, Q. (2009): Water quality in the upper Han River basin, China: the impacts of land use/land cover in riparian buffer zone. - Journal of Hazardous Materials 165(1): 317-324.

[20] Loveland, T.R., Dwyer, J.L. (2012): Landsat: Building a strong future. - Remote Sensing of Environment 122: 22-29.

[21] Mac Donagh, M.E., Casco, M.A., Claps, M.C. (2009): Plankton relationships under small water level fluctuations in a subtropical reservoir. - Aquatic Ecology 43(2): 371-381.

[22] Matthews, M.W., Bernard, S., Winter, K. (2010): Remote sensing of cyanobacteriadominant algal blooms and water quality parameters in Zeekoevlei, a small hypertrophic lake, using MERIS. - Remote Sensing of Environment 114: 2070-2087.

[23] Mengui, M., Luti, R. (1982): Mapa fisonómico de vegetación de la cuenca de alimentación del embalse Río Tercero. Escala 1:250.000. - Ecología Argentina 7: 185194.

[24] Ngoye, E., Machiwa, J.F. (2004): The influence of land use patterns in the Ruvu river watershed on water quality in the river system. - Physics and Chemistry of the Earth 29, 1161-1166.

[25] Nishimura, F., Watanabe, M., Takahashi, R., Akase, T. (2002): Runoff characteristics of nutrients from citrus fruit grove and its effects on water area. - Water Science and Technology 45(12): 37-44.

[26] Oguro, Y., Suga, Y., Takeuchi, S., Ogawa, H., Tsuchiya, K. (2003): Monitoring of a rice field using Landsat-5 TM and Landsat-7 ETM+ data. - Advances in Space Research 32(11), 2223-2228.

[27] Ouedraogo, I., Tigabu, M., Savadogo, P., Compaore, P.C., Ode'N, H., Ouadba, J.M. (2010): Land cover change and its relation with population dynamics in Burkina Faso, West Africa. -Land Degradation \& Development 21(5): 453-462. 
[28] Richards, C., Host, G. (1994): Examining land-use influences on stream habitats and macroinvertebrates: a GIS approach. - Water Resources Bulletin 30, 729-738.

[29] Schulz, J.J., Cayuela, L., Echeverria, C., Salas, J., Rey Benayas, J.M. (2010): Monitoring land cover change of the dryland forest landscape of Central Chile (1975-2008). Applied Geography 30(3): 436-447.

[30] Seeboonruang, U. (2012): A statistical assessment of the impact of land uses on surface water quality indexes. - Journal of Environmental Management 101: 134-142.

[31] Shalaby, A., Tateishi, R. (2007): Remote sensing and GIS for mapping and monitoring land cover and land-use changes in the Northwestern coastal zone of Egypt. - Applied Geography 27(1): 28-41.

[32] Shen, Z., Lu, C., Yin, R., Qi, J. (2013): Land cover changes in northeast China from the late 1970s to 2004. - Applied Ecology and Environmental Research 11(1): 67-78.

[33] Shukla, J.B., Misra, A.K., Chandra, P. (2008): Modeling and analysis of the algal bloom in a lake caused by discharge of nutrients. - Applied Mathematics and Computation 196(2): 782-790.

[34] Su, Z., Lin, C., Ma, R., Luo, J., Liang, Q. (2015): Effect of land use change on lake water quality in different buffer zones. - Applied Ecology and Environmental Research 13(2): 489-503.

[35] Tong, S.T., Chen, W. (2002): Modeling the relationship between land use and surface water quality. Journal of Environmental Management 66(4): 377-393.

[36] Wang, X. (2001): Integrating water-quality management and land-use planning in a watershed context. - Journal of Environmental Management 61:25-36.

[37] Xu, H., Huang, S., Zhang, T. (2013): Built-up land mapping capabilities of the ASTER and Landsat ETM+ sensors in coastal areas of southeastern China. - Advances in Space Research 52(8): 1437-1449. 